\title{
MOGUĆNOSTI UNAPREĐENJA PEDAGOŠKOG SAVETOVANJA U OKVIRU CENTRA ZA PODRŠKU STUDENTIMA FILOZOFSKOG FAKULTETA*
}

\begin{abstract}
Apstrakt. Centar za podršku studentima na Filozofskom fakultetu u Novom Sadu, koji je nedavno aktiviran, usmeren je na realizaciju različitih programa pedagoške i psihološke podrške, usmerenih na očuvanje i unapređivanje mentalnog zdravlja studenata, kao i na postizanje akademskih rezultata. U tom okviru, u radu su prikazani rezultati istraživanja čiji je cilj usmeren na ispitivanje mišljenja studenata o radu i aktivnostima Centra za podršku studentima, sa posebnim osvrtom na aktivnosti iz domena pedagoškog savetovanja. U istraživanju je učestvovao 101 student Filozofskog fakulteta, a korišćeni instrument kreiran je za potrebe ovog istraživanja. Dobijeni rezultati pokazali su da studenti uočavaju značaj delovanja Centra za podršku studentima, kao i lične benefite koje mogu dobiti kroz ovakvu vrstu podrške. Ipak, rezultati sugerišu potrebu intenzivnijeg rada na promociji Centra, kao i na motivisanju studenata za uključivanjem u aktivnosti koje mogu da im pruže dodatne informacije i korisno iskustvo. U skladu sa tim, u završnom delu rada date su implikacije koje upućuju na mogućnosti daljeg unapređenja kvaliteta rada Centra za podršku studentima, a samim tim i na mogućnosti unapređenja pedagoško-savetodavnog rada kao značajnog polja delovanja.
\end{abstract}

Ključne reči: studenti, Centar za podršku studentima, savetodavni rad, mere unapređenja.

\footnotetext{
* Rad je nastao iz okvira master rada Marte Gašpar, koji je odbranjen 02.10.2017. godine, pod mentorstvom prof. dr Slađane Zuković. Takođe, rad je deo aktivnosti na projektu Kvalitet obrazovnog sistema Srbije u evropskoj perspektivi (179010) i Pedagoški pluralizam kao osnova strategije obrazovanja (179036), koje finansira Ministarstvo prosvete, nauke i tehnološkog razvoja Republike Srbije.
}

Marta Gašpar, marticgaspar@gmail.com 


\section{UVOD}

Svaka individua prolazi kroz niz razvojnih perioda tokom kojih se suočava sa različitim promenama i izazovima koji umnogome utiču na tok njegovog razvoja, napredovanja i ukupnog funkcionisanja tokom života. Jedan od perioda koji se smatra posebno značajnim i izazovnim jeste period studiranja. Činjenica je da visokoškolski nivo obrazovanja donosi brojne promene koje su direktno povezane s trenutnim, ali i budućim ponašanjem i delovanjem mladih. Te promene očituju se u promeni sredine, odnosno promeni životnog okruženja, velikom broju novih osoba u okruženju, složenim obavezama sa kojima se studenti susreću i slično. Ovakvo stanje usložnjava i činjenica da svaka individua doživljava pomenute promene na sebi specifičan način. Stoga, imajući u vidu kompleksnost ovog razvojnog perioda, visokoškolske ustanove često osnivaju centar za podršku studentima, i to sa ciljem da se studentima olakša proces adaptacije na novonastale situacije, tj. da im se pruži institucionalna podrška kako bi na adekvatan način prevazišli potencijalne probleme. U okviru ovakvih centara organizuju se različite aktivnosti usmerene na pružanje pomoći i podrške studentima $u$ različitim domenima (prevazilaženje psihosocijalnih problema, pomoć i podrška pri učenju, razvijanje radnih navika i zdravih stilova života, adaptacija na novu okolinu, uspostavljanje adekvatnih socijalnih odnosa, itd). Ukratko rečeno, cilj centra za podršku studentima jeste realizacija različitih programa pedagoške i psihološke podrške u pogledu očuvanja i unapređivanja mentalnog zdravlja studenata, kao i postizanja akademskih rezultata.

S obzirom da je ovakav centar nedavno aktiviran i na Filozofskom fakultetu Univerziteta u Novom Sadu, u ovom radu je, pored kratkog opšteg 
osvrta na značaj i mogućnosti pružanja podrške studentima u ličnom i akademskom razvoju, dat i sažet prikaz aktivnosti Centra za podršku studentima Filozofskog fakulteta. Pored toga, prikazani si i rezultati empirijskog istraživanja o sagledavanju opšte informisanosti i mišljenja studenata o radu i aktivnostima Centra, sa posebnim osvrtom na aktivnosti iz domena pedagoškog savetovanja. Krenulo se od očekivanja da će dobijeni nalazi biti koristan okvir za unapređenje opšteg kvaliteta rada Centra, odnosno da će identifikovane potrebe studenata poslužiti kao smernica za proširivanje sfere delovanja i aktivnosti u vezi sa pedagoško-savetodavnim radom kao veoma značajnim domenom delovanja Centra za podršku studentima.

\section{ZNAČAJ PRUŽANJA PODRŠKE STUDENTIMA U LIČNOM I AKADEMSKOM RAZVOJU}

Činjenica je da se mladi tokom studiranja suočavaju sa brojnim promenama, a samim tim i određenim poteškoćama, zbog čega su im potrebne podrška i pomoć kako bi ih na uspešan način prevazišli (MeščićBlažević, 2007). Prema nalazima jednog istraživanja (Vuković i sar., 2015), identifikovane su neke ključne poteškoće sa kojima se studenti najčešće susreću tokom studiranja:

1. teškoće prilikom upoznavanja nove životne sredine - problemi koji su rezultat neadekvatne adaptacije na nove uslove života;

2. savladavanje nastavnog gradiva - problemi koji nastaju kao posledica nerazvijenih radnih navike i neadekvatnih tehnika i metoda učenja;

3. nedostatak motivacije - kao posledica nedostatka motivacije za učenjem i neadekvatnog pristupa u suočavanju sa postavljenim zahtevima i očekivanjima; 
4. finansijski problemi - posledica nedostatka finansijskih sredstava potrebnih za efikasno studiranje;

5. nastavno osoblje kao izvor problema i teškoća - posledica neadekvatnog odnosa na relaciji profesor-student, što često može biti izvor velikih frustracija i neprijatnosti.

Navedene, ali i brojne druge, poteškoće sa kojima se studenti mogu suočiti tokom školovanja nameću potrebu da visokoškolske ustanove rade na osnivanju različitih službi i centara koji bi studentima pružili odgovarajuću pomoć i podršku, odnosno koji bi doprineli adekvatnom podsticanju razvoja i akademskog napredovanja mladih. Shodno tome, značajno je ukazati na neke od mera podrške koje je moguće realizovati u radu sa studentima (Živadinović i Čekić-Marković, 2015):

1. osnivati i jačati centre koji se odnose na karijeru studenata - pružanje informacija o tome gde mogu da rade tokom studiranja kako bi ublažili nedostatak financijskih sredstava;

2. osnivanje centara u kojima će kao mentori psihološkog i pedagoškog savetovanja delovati stariji studenti;

3. raditi na osnivanju informativnih centara koji će studentima ponuditi relevantne sadržaje - informacije o volontiranju, zdravstevnim uslugama, efikasnom korišćenju slobodnog vremena, programima mobilnosti i sl;

4. obezbediti što više praktične nastave tokom pohađanja osnovnih i master studija, jer na taj način studenti jačaju svoje profesionalne i lične kompetencije.

Osnovu rada centara za podršku studentima treba da čini savetovanje kao proces u kojem savetnik pomaže studentima (kroz individualni ili grupni 
rad) da uoče sopstvene poteškoće, sagledaju različite perspektive za moguća rešenja i načine menjanja neadekvatnih obrazaca svog ponašanja. $\mathrm{Na}$ taj način studenti razvijaju i jačaju sopstvene kapacitete za promene (Zuković, 2017). Ovakav pristup u radu sa studentima podrazumeva i primenu različitih metoda i oblika rada, zavisno od specifičnosti određene problematike, broja studenata kojima je potrebna podrška, kao i njihove motivacije za promenu.

Pored dostupnosti stručnjaka različitih profila (pre svega, pedagozi i psiholozi), pokazalo se da delotvornost pružanja podrške studentima može biti značajno unapređena i kroz uvođenje programa vršnjačkog mentorstva (Dobbie, Joyce, 2008). Naime, program savetodavnog rada u kojem učestvuju mladi kao savetnici, tzv. vršnjački mentori, usvojen je od strane mnogih instituta $\mathrm{i}$ univerziteta širom sveta. To je pristup koji je nastao iz potrebe da se mladima olakša učenje u različitim oblastima (ekonomija, računovodstvo, pravo, medicina i dr). Međutim, ovakav vid delovanja ne bi trebao da se ograniči samo na pružanje pomoći prilikom učenja, već treba da bude i šire usmeren kao vid vršnjačke podrške u procesu razvijanja ličnih potencijala i veština, odnosno kao pomoć u opštem ličnom i akademskom razvoju. Neki autori (Capstick, Fleming \& Hurne, 2004) ističu da se kroz savetodavni vršnjački rad, kao jedan od vidova pružanja podrške u procesu učenja i napredovanja studenata, pruža mogućnost kooperativnog rada $\mathrm{u}$ kojem ulogu mentora imaju starije kolege studenti koji već imaju usvojena znanja, veštine i kompetencije iz određene oblasti. U tom smislu, vršnjačko mentorstvo predstavlja proces sticanja znanja i veština kroz aktivno pomaganje i podržavanje od strane vršnjaka. U ovaj vid rada uključeni su pojedinci iz sličnih socijalnih grupa koji međusobno razmenjuju znanja i 
iskustva, uče jedni od drugih, te na taj način razvijaju pozitivne osobine, kompetencije, veštine (Topping, 2005, prema: Dobbie \& Joyce, 2008).

Svrha vršnjačkog mentorstva nije samo direktno prenošenje znanja odnosno pružanje određenih informacija, već je fokus na procesu razmišljanja, analiziranja i rešavanja određenog problema. Vršnjački mentori imaju zadatak da podstaknu svoje vršnjake da razmišljaju, formulišu i postavljaju pitanja o stvarima i situacijama koje su im nejasne i zbunjujuće. Nakon što su pitanja formulisana, zajedno tragaju za odgovorima i teže da zajedničkim radom otklone potencijalne barijere. To znači da program vršnjačkog mentorstva potpomaže samostalno, dublje i konstruktivnije učenje, aktivno istraživanje informacija i njihovu obradu, te razvijanje kritičkog mišljenja. Programi vršnjačkog mentorstva pružaju mogućnost da se među vršnjacima razvijaju dugotrajna životna prijateljstva značajna za životno funkcionisanje. Takvi odnosi - prijateljstva koja se razvijaju u okviru savetodavnog rada vršnjaka - direktno se reflektuju na akademska postignuća. Naime, vršnjaci mentori mogu da prilagode program savetodavnog rada tako da mlade zainteresuju, motivišu za rad na sebi tj. za usavršavanje sopstvene ličnosti, i to upravo pomoću navođenja ličnih iskustava vrlo bliskih studentima. Na taj se način mladi spremaju za dalji razvoj i napredovanje, kao i za buduće delovanje u društvu (Dobbie \& Joyce, 2008; Gaustad, 1993).

Sve navedeno ukazuje na neophodnost da vršnjački mentori budu adekvatno obučeni za tu ulogu kako bi mogli svojim vršnjacima da pomognu (Dobbie \& Joyce, 2008). U tom smislu, program vršnjačke pomoći i podrške podrazumeva specifičnu edukaciju putem koje studenti-mentori razvijaju potrebna znanja, veštine i sposobnosti za efikasno obavljanje ove uloge. 
Zahvaljujući ovakvim programima, studenti-mentori jačaju i sopstvene kapacitete, razvijaju svoje lične i profesionalne kompetencije, samopouzdanje i trude se da iste i slične osobine prenose na svoje vršnjake (Beasley, 1997; Santee \& Garavalia, 2006), što i jeste cilj vršnjačkog mentorstva.

\section{AKTIVNOSTI CENTRA ZA PODRŠKU STUDENTIMA FILOZOFSKOG FAKULTETA U NOVOM SADU}

Osnivanje Centra za podršku studentima Filozofskog fakulteta $\mathrm{u}$ Novom Sadu predstavlja jednu od mera institucionalne podrške studentima $u$ cilju njihovog ličnog i akademskog razvoja. Činjenica je da očekivane razvojne promene koje se dešavaju tokom studiranja za mnoge mlade osobe predstavaljaju izazov, posebno kada je reč o prvoj godini studiranja kada se mladi odvajaju od porodice i dotadašnjeg socijalnog okruženja, kada se susreću sa izazovima adaptacije na nove životne uslove i zahteve koje postavlja visokoškolski nivo obrazovanja. Takođe, početak studiranja često predstavlja period kada mladi dolaze u situaciju da preispituju svoju ličnost $i$ sopstvene kapacitete za prevazilaženje brojnih izazovnih i nepoznatih situacija sa kojima će se susresti. Iako većina studenata uspeva da se samostalno (ili uz pomoć bliskih osoba) adekvatno izbori sa pomenutim izazovima, nekima je potrebna dodatna podrška. Stoga je veoma važno i postojanje institucionalne podrške koja treba da bude vođena od strane stručnjaka sa visokoškolske institucije. Upravo to je smisao i svrha Centra za podršku studentima Filozofskog fakulteta u Novom Sadu, koji nudi različite programe i sadržaje, odnosno pruža pedagoško-psihološku pomoć kroz različite oblike savetodavnog rada, kako bi studenti na odgovarajući način savladali (ne)očekivane razvojne krize i na taj način postali efektivniji i uspešniji u studiranju. 
Osnovni cilj Centra za podršku studentima Filozofskog fakulteta $\mathrm{u}$ Novom Sadu jeste uvođenje programa pedagoške i psihološke pomoći studentima u cilju njihovog opšteg razvoja i napredovanja. Nosioci realizacije predviđenih aktivnosti Centra su stručnjaci sa Odseka za pedagogiju i sa Odseka za psihologiju Filozofskog fakulteta u Novom Sadu, pri čemu je predviđeno i uključivanje stručnjaka iz drugih oblasti i ustanova kada za to ima potrebe. Aktivnosti Centra sprovode se putem dve vrste programa: 1 . program unapređenja mentalnog zdravlja i blagostanja studenata; 2. program unapređenja veština i kompetencija koje su potrebne za učenje i prevazilaženje barijera u studiranju (dostupno na: http://www.ff.uns.ac.rs/ fakultet/centar_za_podrsku_studentima/CPSStudijaIzvodljivosti.pdf).

Realizacija predviđenih aktivnosti ostvaruje su putem individualnog ili grupnog savetodavnog rada koji se najčešće ostvaruje putem pedagoškopsiholoških radionica. Kada je u pitanju program individualnog savetodavnog rada, njegov je cilj da studenti dobiju podršku u procesu razvijanja strategija za unapređenje uspeha u učenju i postizanju akademskih rezultata, kao i strategija za suočavanje sa problemima i teškoćama. Očekivani ishodi individualnog savetovanja su: da studenti ovladaju različitim metodama i tehnikama učenja, što će doprineti lakšem savladavanju nastavnog gradiva; unapređenje motivacije za učenje i akademska postignuća; priprema za pružanje podrške vršnjacima tj. kolegama studentima; osnaživanje studenata na poljima ličnog i profesionalog razvoja i sl. S druge strane, aktivnosti Centra u obliku grupnog oblika rada imaju za cilj da studenti dobiju adekvatne informacije o procesu studiranja i da razvijaju socijalne veštine potrebne za postizanje uspeha u učenju i u odnosima sa drugima. Očekivani ishodi ovih radionica jesusu: osvešćivanje studenata da na problem treba 
gledati iz više perspektiva i da ga je moguće rešiti na više načina; motivisanje studenata da preuzimaju odgovornost za sopstvene postupke i odluke; bolje snalaženje u partnerskim odnosima i razvijanje osetljivost za tuđe probleme; osposobljavanje studenata za kvalitetnu i uspešnu komunikaciju sa drugima; jačanje ličnosti studenata kada je u pitanju javni nastup i uspešno izlaganje pred drugima i slično (dostupno na: http://www.ff.uns.ac.rs/fakultet/centar_ za_podrsku_studentima/CPSStudijaIzvodljivosti.pdf).

Poseban segment rada Centra koji se odnosi na pedagoškosavetodavni rad usmeren je na osnaživanje studenata u cilju efikasnog studiranja; obuhvata sledeće sadržaje:

1. učenje učenja - tehnike i metode uspešnog i kvalitetnog učenja; izbor adekvatnih strategija učenja; pomoć pri organizaciji procesa učenja; pomoć prilikom rešavanja teškoća u učenju; motivacija za učenje;

2. lični i profesionalni razvoj studenata - pomoć pri planiranju ličnog i profesionalnog razvoja; analiza razvojnih potreba studenata; postavljanje ciljeva; motivacija za ostvarivanje postavljenih ciljeva; realizacija, praćenje i evaluacija ostvarenosti postavljenih ciljeva ličnog i profesionalnog razvoja; 3. veštine komunikacije - timski i grupni rad; asertivna komunikacija; aktivno slušanje i razumevanje;

4. veštine prezentovanja - priprema za prezentaciju; adekvatno prenošenje poruka drugima; uspešna interakcija s učesnicama; evaluacija prezentacije, odnosno povratna informacija o realizovanoj prezentaciji na osnovu diskusije sa drugima (dostupno na: http://www.ff.uns.ac.rs/fakultet/centar_ za_podrsku_studentima/Program\%20rada\%20pedagoskog\%20servisa.pdf).

Svi navedeni segmenti rada od izuzetnog su značaja ne samo za uspešno studiranje, već i za kvalitetno funkcionisanje u savremenom društvu. 
Zahvaljujući pomenutim aktivnostima, Centar pruža mogućnost da se studentima obezbede povoljniji uslovi studiranja, odnosno da im se pruži prilika da shvate da im je potrebna određena podrška, te da znaju kome da se obrate za pomoć. Da bi se sve to ostvarilo, potrebno je da Centar prati koje su potrebe studenata $\mathrm{i}$ da na osnovu toga organizuje i realizuje ciljane i svrsishodne aktivnosti, s tim što će u njihovu realizaciju uključiti i same studente kao savetnike/edukatore $\mathrm{i}$ na taj način jačati njihove lične $\mathrm{i}$ profesionalne kompetencije. $U$ tu svrhu realizovano je i empirijsko istraživanje, čiji će rezultati biti prikazani u daljem tekstu.

\section{METODOLOGIJA ISTRAŽIVANJA}

Cilj i zadaci istraživanja

Cilj istraživanja usmeren je na ispitivanje mišljenja studenata Filozofskog fakulteta o radu i aktivnostima Centra za podršku studentima, kao i na ispitivanje njihovog mišljenja o oblastima u kojima bi Centar mogao da im pruži dodatnu podršku. Na osnovu postavljenog cilja, operacionalizovani su sledeći istraživački zadaci: 1) utvrditi da li su studenti upoznati sa radom i aktivnostima Centra za podršku studentima, te da li su učestvovali u nekim od organizovanih aktivnosti; 2) ispitati koje oblasti rada Centra studenti smatraju značajnim za razvoj i napredovanje studentske populacije; 3) utvrditi mišljenje studenata o tome ko treba da budu mentori (savetnici) u Centru za podršku studentima; 4) sagledati mišljenje studenata o važnosti pedagoško-savetodavnog rada koji se realizuje u okviru Centra; 5) ispitati mišljenje studenata o opštim potrebama studenata i njihovim ličnim potrebama koje bi Centar mogao da zadovolji; 6) ispitati mišljenje studenata o mogućnostima unapređenja rada Centra. 
Metode, tehnike i instrument istraživanja

U istraživanju je korišćena deskriptivna metoda pomoću koje je izvršen pregled (snimanje) stanja sa ciljem dobijanja što iscrpnijeg opisa stvarnih, odnosno postojećih činjenica. Korišćena je tehnika anketiranja a kao instrument upitnik koji je konstruisan za potrebe ovog istraživanja. Upitnik se sastajao od 14 pitanja otvorenog i zatvorenog tipa. Jedna grupa pitanja u upitniku odnosila se na opšte podatke o studentima, nakon čega su sledila pitanja o poznavanju rada i delovanja Centra za podršku studentima.

\section{Uzorak i tok istraživanja}

Uzorkom je bio obuhvaćen 101 student Filozofskog fakulteta u Novom Sadu. Od ukupnog broja ispitanika, većinu su činili studenti četvrte godine osnovnih akademskih studija (40) i master studija (31). Nešto manji broj ispitanika bili su studenti treće godine studije (12), a po 9 ispitanika su bili studenti prve i druge godine studija. Kada je reč o obrazovnom profilu, u najvećem broju učestvovali su studenti pedagogije (52), zatim studenti koji pohađaju jezički smer (anglistika - 4, germanistika - 3, romanistika - 11, slavistika - 2, slovakistika - 2, srpski jezik i lingvistika - 4), kao i studenti koji pohađaju filozofiju (5), sociologiju (4), istoriju (5), psihologiju (5) i žurnalistiku (4). Na osnovu ovih podataka, može se zaključiti da su u istraživanju učestvovali studenti sa većine akademskih odseka koji se realizuju na Filozofskom fakultetu u Novom Sadu. Istraživanje je sprovedeno tokom školske 2016/2017 godine. Najveći broj studenata (71) je upitnik popunio putem interneta (onlajn), dok je 30 studenata popunjavalo upitnik u štampanoj formi. 


\section{REZULTATI ISTRAŽIVANJA}

Upoznatost sa radom Centra za podršku studentima i učestvovanje u organizovanim aktivnostima. - Rezultati su pokazali da je 68 studenata (67\%) upoznato sa radom Centra za podršku studentima, a 33 studenta (34\%) uopšte nije upoznato da takva vrsta centra postoji. Takođe, rezultati pokazuju da od ukupno $67 \%$ studenata koji navode da su upoznati sa radom i aktivnostima Centra za podršku studentima, samo $8 \%$ njih se i aktivno uključivalo $\mathrm{u}$ te aktivnosti. Kao razloge zbog kojih nisu učestvovali $\mathrm{u}$ aktivnostima i radionicama, studenti navode sledeće: nedostatak vremena; aktivnosti organizovane za vreme trajanja drugih obaveza na fakultetu; nezanimljiv sadržaj radionica; nedovoljna informisanost o planiranim aktivnostima (Grafik 1).

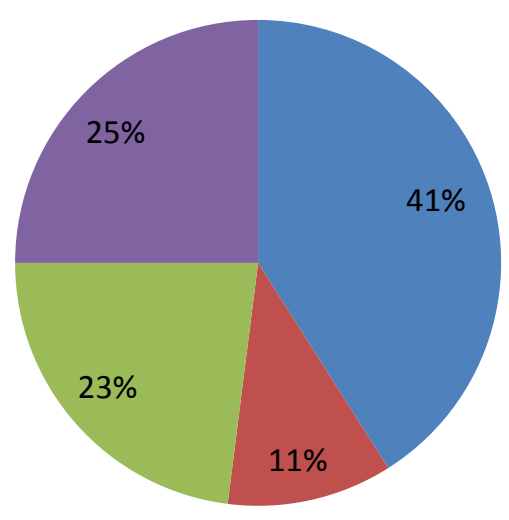

- Nedostatak vremena

Nezanimljiv sadržaj

Neinformisanost

Aktivnosti organizovane za vreme drugih obaveza na fakultetu

Grafik 1. Razlozi neučestvovanja studenata u aktivnostima

Oblasti rada Centra koje bi bile značajne za razvoj i napredovanje studenata. - Studenti su iznosili mišljenje o oblastima rada koje oni smatraju 
značajnim za razvoj i napredovanje studentske populacije. Nakon kategorizacije dobijenih odgovora, identifikovane su tri oblasti koje studenti smatraju poželjnim (Grafik 2).

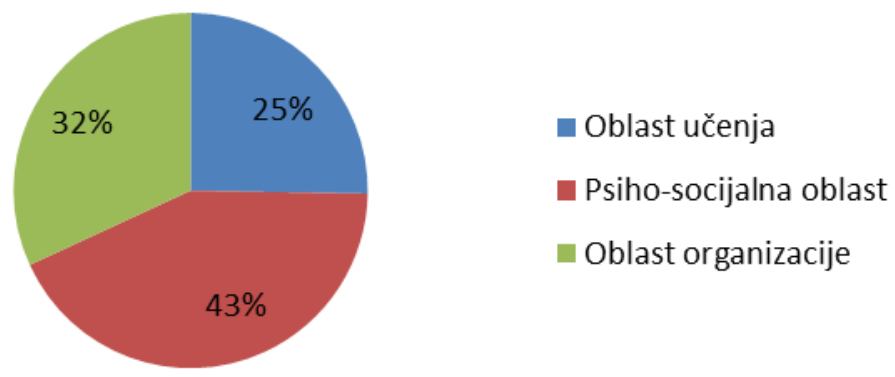

Grafik 2. Poželjne oblasti rada u okviru Centra za podršku studentima

Oblast učenja. - Trebalo bi da Centar studentima ukaže na postojanje različitih metoda i stilova učenja u cilju efikasnijeg i produktivnijeg studiranja. Važnost ove oblasti posebno ističu studenti prve godine studija jer se suočavaju sa obimnim nastavnim gradivom i novim obavezama.

Psiho-socijalna oblast - pomoć i podrška oko prevladavanja određenih stresnih situacija. - Tri ispitanika navode kako su se tokom studija osećala diskriminisano, te smatra da bi Centar trebalo da ponudi aktivnosti koje bi obuhvatile sadržaje o pravima studenata, kao i o razvijanju svesti i prihvatanju različitosti.

Oblast organizacije - pružanje podrške oko toga kako kvalitetno provoditi slobodno vreme. - Posebno važnim studenti ističu mogućnost volontiranja tokom studiranja jer smatraju da im to može pomoći da stiču praktična znanja i iskustvo.

Mentorstvo u okviru Centra za podršku studentima. - Studentima je pružena prilika da navedu ko bi, prema njihovom mišljenju, trebalo da budu mentori u Centru za podršku studentima. Pored asistenata, koje 36\% 
ispitanika smatra kompetentnim da budu mentori, $34 \%$ studenata navodi da bi mentori trebalo da budu i sami studenti. Pored toga, $24 \%$ ispitanika smatra da profesori treba da budu mentori zbog toga što su stručnjaci u svom domenu rada i mogu studentima da pruže kvalitetna znanja i informacije, dok $6 \%$ ispitanika ističe da bi bilo poželjno da u rad Centra budu uključeni i stručnjaci iz drugih ustanova i institucija jer na taj način studenti mogu da usvajaju znanja iz različitih oblasti rada (Grafik 3).

Profesori $\square$ Asistenti $\square$ Studenti $\square$ Stručnjaci iz drugih oblasti rada

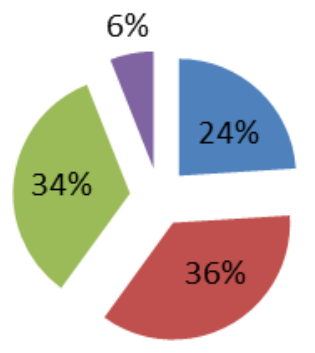

Grafik 3. Mentori u okviru Centra za podršku studentima

\section{Značaj pedagoško-savetodavnog rada u okviru Centra za podršku}

studentima. - Jedan od zadataka istraživanja odnosio se na sagledavanje mišljenja studenata o značaju pedogoško-savetodavnog rada u okviru Centra. Veliki broj ispitanika (75\%) smatra da je pedagoško-savetodavni rad vrlo značajan, dok njih 25\% nije bilo sigurno, odnosno nije moglo sa sigurnošću da proceni da li je pedagoško-savetodavni rad značajan za razvoj ličnosti studenata (Grafik 4). 
Jeste, smatram da je pedagoško-savetodavni rad veoma značajan

- Nisam siguran/a

Ne, mislim da nije neophodan

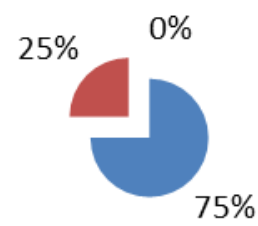

Grafik 4. Značajnost pedagoško-savetodavnog rada

Kvalitativna analiza obrazloženja datih odgovora je pokazala sledeće: 79\% studenata koji su pedagoško-savetodavni rad procenili značajnim smatra da ovakav vid podrške može biti koristan za prevladavanje raznovrsnih problema (strah od javnog nastupa, stresne situacije i anksioznost zbog ispita, nedoumice, nisko samopouzdanje, pomoć prilikom učenja, razvoj motivacije i sl). Značajan broj ispitanika (21\%) koji su pedagoško-savetodavni rad procenili kao veoma značajan nije dao obrazloženje zbog čega bi im ovaj vid podrške mogao biti koristan.

\section{Potrebe studenata koje bi Centar za podršku studentima trebao da} zadovolji. - Ispitanicima je pružena mogućnost da iskažu koje su opšte potrebe studentske populacije, kao i njihove lične potrebe, koje bi Centar za podršku studentima trebalo da zadovolji.

Analiza je pokazala da većina dobijenih odgovora o opštim potrebama studentske populacije spada u psiho-socijalnu oblast (43\%) i odnosi se na potrebu podrške studentima prilikom rešavanja problema, adaptacije na okruženje, razvijanja međuljudskih odnosa i socijalizacije, jačanja samopouzdanja, suočavanja sa depresijom itd. Odgovori koji spadaju u oblast učenja (34\%) odnose se na potrebu studenata za razvijanjem efikasnih stilova učenja (upoznavanje različitih metoda i strategija učenja), 
dok 23\% ispitanika ističe potrebe koje spadaju u oblast organizacije informacije o tome na koji način bi mogli sticati praktična znanja i iskustva, potom priprema za ulazak u svet rada (pisanje biografija, razgovor sa poslodavcem).

Kada su u pitanju lične potrebe studenata, najveći broj ispitanih studenata $(30 \%)$ shvata Centar za podršku studentima kao resurs za jačanje njihovog samopouzdanja, rešavanja nesporazuma sa profesorima i adaptacije na životnu okolinu. Značajan broj njih (25\%) ističe da bi se obratili Centru zbog teškoća prilikom učenja, dok je $16 \%$ studenata navelo da bi otišli u Centar radi pomoći u organizaciji slobodnog vremena, radi upoznavanja programa za mobilnost studenata i programa volonterskog rada. Pored navedenog, važno je da $29 \%$ ispitanika ističe da se ne bi obratili Centru za podršku studentima jer nisu sigurni koliko će njihovi iskazi ostati u tajnosti.

\section{Mogućnosti unapređenja rada Centra za podršku studentima. -}

Kada su u pitanju mere unapređenja rada Centra, dobijeni rezultati prikazani su na Grafiku 5.

- Promocija $\square$ Saradanja sa studentima $\quad$ Bez predloga

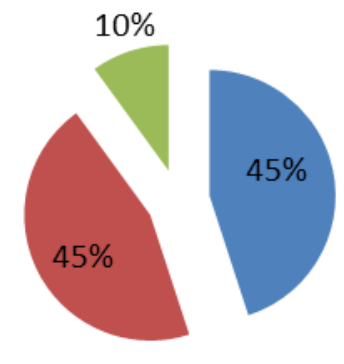

Grafik 5. Predlozi studenata za unapređenja Centra za podršku studentima

Dobijeni nalazi pokazuju da $45 \%$ studenata smatra da bi trebalo više raditi na promociji Centra. Kako bi njegova promocija bila na višem i kvalitetnijem nivou, studenti predlažu da Centar bude aktivan na društvenim 
mrežama (fejsbuk), da bude transparentan, kao i da osnuje studentski časopis koji bi se sastojao od radova studenata koji pišu tokom studiranja. Takođe, 45\% ispitanika smatra da Centar treba da unaperedi odnose sa studentima odnosno da češće organizuje okupljanje studenata kako bi im se predstavili ciljevi i aktivnosti Centra. Mišljenja su da bi trebalo organizovati radionice i druge aktivnosti u koje bi studenti bili aktivno uključeni, te da bi trebalo da budu pitani o tome šta im je potrebno, pa da se na osnovu toga osmišljavaju različite aktivnosti. Pored navedenih mogućih predloga za unapređenje rada Centra za podršku studentima, $10 \%$ studenata navodi da zbog toga što nisu u dovoljnoj meri upoznati sa dosadašnjim radom Centra - ne mogu ni da daju konkretne predloge kako da se unapredi rad.

\section{DISKUSIJA I ZAKLJUČNA RAZMATRANJA}

Kao što je već u nekoliko navrata spomenuto, studiranje predstavlja jedan od razvojnih perioda koji zahteva pružanje kvalitetne institucionalne podrške studentima. Koliko je to važno, potvrđuju i rezultati predstavljenog istraživanja. Naime, dobijeni nalazi govore o tome da većina ispitanih studenata jeste upoznata da na Filozofskom fakultetu deluje Centar za podršku studentima, ali da je ipak neophodno još više raditi na njegovoj promociji. To potkrepljuje i nalaz o tome da upoznatost sa radom Centra ne znači i aktivno korišćenje usluga koje se nude, jer su rezultati pokazali da je uključenost studenata $\mathrm{u}$ aktivnosti i radionice prethodno organizovane bila minimalna. Drugim rečima, potrebno je mnogo više raditi na motivisanju studenata za uključivanje u aktivnosti koje mogu da im pruže dodatne informacije i korisno iskustvo. 
Kada je u pitanju pedagoško-savetodavni rad, studenti uočavaju njegov značaj i smatraju da im taj segment rada Centra može pružiti odgovarajuću pomoć i podršku, posebno kada je reč o procesu učenja. Međutim, značajan je i broj onih studenata koji ističu da se ne bi obratili za pomoć jer sumnjaju u nivo poverljivosti iznetih informacija o sopstvenim problemima i poteškoćama. Ovakav nalaz takođe govori u prilog značaja motivisanja i kreiranja atmosfere poverenja u kojoj će studenti shvatiti da je Centar osnovan upravo zbog njih i njihovih potreba. Po pitanju mentorstva, ispitanici su naveli da bi u Centru, pored profesora i asistenata, trebalo što više da budu angažovani i studenti-mentori, što bi vremenom trebalo da postane praksa kojoj će Centar sve više težiti.

Generalno posmatrano, dobijeni nalazi sugerišu da studenti uoče da Centar za podršku studentima jeste značajan i da može biti veoma koristan jer obuhvata širok spektar aktivnosti i oblasti rada koje mogu doprineti razvoju i napredovanju studentske populacije. Slično mišljenje o značaju centara imali su i studenti iz Hrvatske koji su učestvovali u istraživanju koje je sprovedeno 2012. godine na Univerzitetu u Zagrebu (Drusany et al., 2012), a koje je imalo za cilj da ispita koje su potrebe studenata tokom procesa studiranja, odnosno iz kojih oblasti rada i delovanja im je potrebna dodatna podrška i pomoć. $\mathrm{Na}$ osnovu rezultata tog istraživanja vidi se mišljenje studenata o tome da službe ili centri namenjeni njima, pored podrške u vezi sa procesom učenja i akademskog napredovanja, treba da budu usmereni i na njihove emocionalne i socijalne probleme, koji u ovom preriodu nisu ništa manje važni. Čini se da sličan zaključak može biti izveden i na osnovu mišljenja studenata Filozofskog fakulteta u Novom Sadu. 
Na osnovu svega, može se zaključiti da postoje brojne mogućnosti za unapređenje rada Centra za podršku studentima, a samim tim i za mogućnosti unapređenja pedagoško-savetodavnog rada kao značajnog polja delovanja. Jedan od načina jeste intenzivnije realizovanje modela radioničarskog rada sa studentima. Radionice bi trebalo da se bave raznovrsnim temama koje su uzajamno povezane i deluju na pravilan razvoj ličnosti studenata. Moguće teme odnosno radionice mogu da se odnose na:

1. osvešćivanje ličnih kapaciteta, ambicija i očekivanja - uočavanje ličnih afiniteta i mogućnosti mladih osoba, odnosno pružanje mogućnosti da studenti prihvate sopstvene slabosti i snage i realnu sliku o sebi i na taj način rade na sopstvenom usavršavanju;

2. učenje učenja - pruženje mogućnosti da studenti upoznaju i primene različite strategije i metode učenja koje bi doprinele njihovom akademskom postignuću;

3. podizanje samopouzdanja - razvijanje svesti o sebi odnosno poštovanju, vrednovanju i verovanju u sebe kao ličnost, kao i postavljanje ciljeva koji su realni i ostvarivi;

4. veštine savladavanja treme i straha od javnog nastupa - jačanje kompetencije javnog nastupa i kontakta sa drugima; većina obaveza na fakultetu sastoji se od javnog izlaganja određenih tema, zbog čega je studentima potrebno pružiti dodatnu podršku kako bi što uspešnije savladali tremu i strah od javnog prezentovanja;

5. savladavanje oblika asertivnog ponašanja - jačanje ličnosti studenata kroz segment uočavanja i jasnog iskazivanja sopstvenih osećanja i potreba i granica, a bez ugrožavanja osećanja i potreba drugih; 
6. ovladavanje tehnikama efikasne komunikacije - upoznavanje sa različitim tehnikama jasne $\mathrm{i}$ otvorene komunikacije kako bi se predupredile situacije da određene poruke ne budu prihvaćene i shvaćene na odgovarajući način;

7. održavanje motivacije za učenje putem bolje organizacije vremena pomoć prilikom planiranja i organizovanja skobodnog vremena, odnosno uspostavljanja adekvatnog balansa između fakultetskih obaveza i potrebe za socijalnim životom.

Uopšteno posmatrano, cilj radioničarskog modela rada treba da bude usmeren na jačanje ličnosti studenata i na pružanje odgovarajuće podrške kako bi što uspešnije odgovorili na zahteve koji se odnose na proces studiranja, ali i osnažili lične kompetencije i sposobnosti. Realizovanjem ovakvih tipova radionica, Centar za podršku studentima može da unapredi svoj rad, odnosno da svoju transparentnost i promociju podigne na viši nivo. Samim tim, moguće je delovati i uticati i na motivaciju studentske populaciju da se aktivnije uključi u rad Centra.

\title{
POSSIBILITIES FOR IMPROVING PEDAGOGICAL COUNSELING IN THE FRAMEWORK OF THE SUPPORT CENTER FOR STUDENTS AT THE FACULTY OF PHILOSOPHY
}

\begin{abstract}
The Support Center for Students at the Faculty of Philosophy in Novi Sad, which has been recently activated, is focused on the implementation of various programs for pedagogical and psychological support. These programs have the aim to preserve and improve student's mental health in order to achieve their academical results.

The paper shows the results of the research, which aim was to examine student's opinion on the activities and work of the Center, especially on pedagogical counseling. 101 students of the Faculty of Philosophy participated in this research, and there was used an instrument created for this activity. Results showed that the students recognized the importance of this Center, and benefits which this Center can provide to them. However, the results suggests that it is necessary to work more on the promotion of the Center, as well as on the motivation of students to get involved in its activities. Therefore, the last segment of this paper contains
\end{abstract}


the implications which show possibilities of how to improve work of the Support Center for Students at the Faculty of Philosophy, and how to improve its very important pedagogicaladvisory area.

KEY WORDS: student, Support Center for Students, advisory services, measures of improvement. 


\section{REFERENCE}

Beasley, C. (1997). Students as teachers: The benefits of peer tutoring. Learning Through Teaching. The Proceedings of the $6^{\text {th }}$ Annual Teaching Forum, 21-30. Murdoch University.

Capstick, S., Fleming, H. \& Hurne, J. (2004). Implementing Peer Assisted Learning in Higher Education: The experience of a new university and a model for the achievement of a mainstream program. http://www.unibielefeld.de/Universitaet/Einrichtungen/SLK/peer_lear ning/pal/pdf/implementing_peer_learning_in_higher_education.pdf, 26.03.2017.

Dobbie, M. \& Joyce, S. (2008). Peer-Assisted Learning in Accounting, A Qualitative Assessment. Asian Social Science, 4 (3), 18-25.

Drusany, D., Ajduković, M., Divjak, B., Jokić-Begić, N., Kranželić, V., Rimac, I. (2012). Istraživanje procjene potreba studenata za podrškom tijekom studiranja. Sveučilište u Zagrebu.

Gaustad, J. (1993). Peer and cross-age tutoring. ERIC Digests, 79, 1-6.

Meščić-Blažević, Lj. (2007). Pedagoška prevencija poremećaja u ponašanju adolescenata. Pedagogijska istraživanja, 4 (2), 301-308.

Santee, J. \& Garavalia, L. (2006). Peer Tutoring in Health Professions Schools. American Journal of Pharmaceutical Education, 70 (3), 110.

Vuković, D., Cvejić, S., Ganić, S., Nerubacki, I., Poleti, D. (2015). Služba za podršku studentima - analiza opcija. U Đorić G. (Ur.) Socijalna dimenzija visokog obrazovanja - analize i preporuke (119-133). Niš: Filozofski fakultet. 
Zuković, S. (2017). Savetodavni rad u institucijama vaspitanja i obrazovanja - teorijski i praktični aspekti. Novi Sad: Filozofski fakultet.

Živadinović, I., Čekić-Marković, J. (2015). Mere izjednačavanja šansi u visokom obrazovanju - analize i preporuke. U Đorić, G. (Ur.) Socijalna dimenzija visokog obrazovanja - analize i preporuke (7999). Niš: Filozofski faklultet. 
